\title{
PERSEPSI DAN PARTISIPASI STAKEHOLDER DALAM PENYUSUNAN RENCANA ZONASI WILAYAH PESISIR DI KABUPATEN JEPARA (STUDI KASUS: DESA BANDENGAN KECAMATAN JEPARA)
}

\author{
Perception and Participation of Stakeholder in Coastal Areas Zoning \\ Plan Coastal Areas of Jepara (Case Study: Bandengan Village, Jepara)
}

\section{Pratiwi Rahmawati ${ }^{1}$, Mussadun ${ }^{2}$}

\begin{abstract}
Abstrak: Penelitian ini bertujuan untuk mengkaji persepsi dan partisipasi stakeholder dalam penyusunan rencana zonasi wilayah pesisir. Metode dalam penelitian ini yaitu kualitatif mengggunakan wawancara mendalam dan observasi. Teknik sampling dan analisisnya menggunakan snowball sampling dan analisis interaktif berdasarkan Miles dan Huberman (1992). Hasil penelitian menunjukkan bahwa tahapan penyusunan rencana zonasi wilayah pesisir di Kabupaten Jepara mengalami perubahan yang disesuaikan dengan peraturan terbaru yaitu Permen KP No. 23 Tahun 2016 tentang perencanaan pengelolaan wilayah pesisir dan pulau-pulau kecil. Stakeholder pesisir terkait dengan kegiatan penyusunan rencana zonasi wilayah pesisir di Kabupaten Jepara dibagi menjadi tiga kelompok yaitu stakeholder utama, stakeholder pendukung, dan stakeholder kunci. Persepsi dan partisipasi stakeholder utama berdasarkan frekuensi kehadiran, tingkat keaktifan, dan tingkat pemahaman dapat dikategorikan "rendah". Sebaliknya, stakeholder kunci mempunyai persepsi dan partisipasi berdasarkan frekuensi kehadiran, tingkat keaktifan, dan tingkat pemahaman yang dikategorikan "tinggi". Berbeda halnya, stakeholder pendukung mempunyai persepsi dan partisipasi berdasarkan frekuensi kehadiran dan tingkat keaktifan yang dikategorikan "tinggi", tetapi tingkat pemahaman yang dikategorikan "sedang".
\end{abstract}

\section{Kata Kunci : persepsi, partisipasi, stakeholder, Desa Bandengan}

\begin{abstract}
This study aims to assess the perceptions and participation of stakeholders in the preparation of the coastal areas zoning plan. The method in this research that use qualitative with in-depth interviews and observation. Sampling and analysis techniques using snowball sampling and interactive analysis by Miles and Huberman (1992). The results showed that the different stages of the coastal region zoning plan of Jepara changed to suit the latest regulations Permen KP No. 23 Year 2016 concerning the planning management of coastal areas and small islands. Coastal stakeholders related to drafting a coastal region zoning plan of Jepara divided into three groups: the main stakeholder, stakeholder support, and key stakeholders. Perception and participation of major stakeholders based on the frequency of attendance, activity level, and the level of understanding can be categorized as "low". Instead, key stakeholders have the perception and participation based on the frequency of attendance, activity level, and the level of understanding that is categorized as "high." By contrast, supporters stakeholders have the perception and participation based on the frequency of attendance and the level of activity which is categorized as "high," but the level of understanding that is categorized as "medium."
\end{abstract}

Keywords: perception, participation, stakeholder, Bandengan Village

\footnotetext{
${ }^{1}$ Magister Perencanaan Wilayah dan Kota, Universitas Diponegoro, Semarang

${ }^{2}$ Departemen Perencanaan Wilayah dan Kota, Fakultas Teknik Universitas Diponegoro, Semarang
} 


\section{PENDAHULUAN}

Perkembangan wilayah pesisir dapat menimbulkan manfaat yang besar bagi pembangunan tetapi juga berdampak negatif terhadap lingkungan sehingga memerlukan upaya perencanaan penataan ruang sebagai upaya mengantisipasi konflik penggunaan dan degenerasi lingkungan pesisir. Sebagaimana halnya dilakukan di India yang menggunakan perencanaan tata ruang dalam pengelolaan wilayah pesisir terpadu untuk mengantisipasi konflik pemanfaatan ruang dan menjaga keberlanjutan sumberdaya pesisir (Gangai dan Ramachandran, 2010). Pembatasan pemanfaatan ruang (zonasi) di wilayah pesisir merupakan hal yang sangat penting untuk segera dilakukan, mengingat bahwa berbagai pihak berlomba untuk memanfaatkan ruang di wilayah pesisir. Giz (2013) menyatakan bahwa Filipina menggunakan sistem zonasi dalam membatasi penggunaan sumberdaya pesisir. Negara-negara di Eropa selatan seperti Perancis, Italia, Portugal, Malta, dan Spanyol juga menerapkan sistem zonasi dalam pengelolaan wilayah pesisir terpadu dalam rangka mengatur penggunaan lahan wilayah pesisir (Mangi \& Austen, 2008). Sistem zonasi wilayah pesisir juga berhasil diterapkan di Jerman dengan memadukan sistem pembatasan akses sumberdaya dalam rangka mengatasi konflik pariwisata dan konservasi. (Kindermann dan Gormally, 2013).

Indonesia sendiri mulai menerapkan sistem zonasi dalam rangka pengaturan wilayah pesisir sejak tahun 2007 dengan dikeluarkannya UU No. 27 Tahun 2007 yang kemudian diubah menjadi Undang-Undang Nomor 1 Tahun 2014 tentang pengelolaan wilayah pesisir dan pulau-pulau kecil. Sebagai implementasi dari UU No. 27 Tahun 2007, setiap daerah yang berbatasan langsung dengan laut diwajibkan menyusun rencana zonasi wilayah pesisir sebagai pedoman dalam melakukan pemanfaatan ruang pesisir dan laut. Begitupun dengan Kabupaten Jepara yang berbatasan langsung dengan Laut Jawa sehingga mempunyai kewajiban melakukan kegiatan penyusunan rencana zonasi wilayah pesisir. Rencana zonasi wilayah pesisir merupakan salah satu upaya pengelolaan wilayah pesisir terpadu yang dijadikan sebagai acuan atau pedoman dalam perencanaan dan pembangunan wilayah pesisir di Indonesia. Berbeda halnya, Malaysia menggunakan "Rencana Nasional Wilayah Pesisir" sebagai pedoman dalam pengelolaan wilayah terpadu dalam rangka mengatasi adanya konflik penggunaan (Asmawi et.al, 2012). Irlandia menerapkan "Rencana Konservasi Pesisir" sebagai strategi terpadu untuk memastikan penggunaan ruang secara bijaksana dan berlanjut di wilayah pesisir (Ourcast, 2010). Wilayah pesisir Munakata Jepang menerapkan Pedoman Komprehensif Pengelolaan Wilayah Pesisir pada tahun 2000 dan Undang-Undang Dasar Kebijakan Samudra pada tahun 2007 sebagai upaya dalam rangka mengatasi konflik penggunaan lahan antara sektor pariwisata bahari dan perikanan (Kojima et.al, 2013).

Penyusunan rencana zonasi wilayah pesisir tidak terlepas dari adanya peran persepsi stakeholder atau pemangku kepentingan yang dapat mempengaruhi keberhasilan dari kegiatan tersebut. Kerr (2005) mengemukakan bahwa salah satu metode yang digunakan untuk mengukur keberhasilan strategi pengelolaan wilayah pesisir terpadu yaitu dengan analisis persepsi stakeholder. Peres (2016) berpendapat bahwa persepsi stakeholder dapat digunakan untuk mengidentifikasi dampak lingkungan di wilayah pesisir yang terjadi pada masa lalu akibat tidak adanya data dan pemantauan yang efektif. Thomas et.al (2015) mengemukakan bahwa penelitian persepsi dalam konteks pengelolaan wilayah pesisir menyediakan alat untuk melihat pesisir dan laut melalui beberapa sudut pandang dimana pembaca dapat menginterpretasikan wilayah pesisir dan upaya konservasi pesisir. Himes (2007) berpendapat bahwa persepsi stakeholder diharapkan mampu mengungkapkan preferensi stakeholder mengenai tipe pengelolaan wilayah pesisir yang disukai dan intervensi pengelolaan di masa depan yang sesuai dengan karakteristik wilayah pesisir. Preferensi stakeholder merupakan salah satu variabel yang digunakan untuk 
mengidentifikasi daerah-daerah paling cocok untuk berbagai tingkat zonasi perlindungan dan pemanfaatan dalam perencanaan zonasi wilayah pesisir (Portman, 2007).

Persepsi stakeholder diharapkan mampu menentukan partisipasi stakeholder terhadap kegiatan tersebut. Long Chen et.al (2015) mengemukakan bahwa persepsi stakeholder merupakan faktor penting yang mempengaruhi partisipasi stakeholder pada pengelolaan wilayah pesisir di Taiwan Barat. Keterlibatan stakeholder telah terbukti dalam menghasilkan keputusan yang baik serta mengurangi biaya perencanaan dalam pengelolaan wilayah pesisir secara terpadu (Yates, 2014). Partisipasi stakeholder menjadi kunci dalam memahami perbedaan persepsi stakeholder serta cerminan dari implementasi perencanaan dan pengelolaan wilayah pesisir di Chile Utara (Carcamo et.al, 2014). Sementara itu, partisipasi stakeholder merupakan faktor yang penting yang menentukan keberhasilan suatu pembangunan serta merupakan salah satu pilar dari good governance di Alberta, Kanada (Montgomery et.al, 2016). Abelshausen et.al, (2015) mengemukakan bahwa stakeholder mulai berperan aktif dalam pembangunan wilayah pesisir di Vietnam ketika terdapat kemudahan dalam akses untuk menyampaikan pendapat. Ramsey et.al (2015) juga mengungkapkan keberhasilan pengelolaan wilayah pesisir terpadu dengan pelibatan stakeholder di Pulau Antibuda dan Barbuda Kepulauan Karibia serta Barbados dalam rangka mengatasi penurunan daya dukung lingkungan pesisir akibat pemanfaatan berlebih berupa perikanan tangkap dan pariwisata bahari serta diperparah oleh tingginya abrasi.

Desa Bandengan merupakan salah satu desa pesisir di Kabupaten Jepara yang mempunyai garis pantai terpanjang di Kecamatan Jepara yang mengindikasikan besarnya potensi pariwisata bahari serta sumberdaya kelautan dan perikanan sehingga mendorong perlunya penataan ruang wilayah pesisir berbasis zonasi. Beberapa masalah yang dapat dikemukakan yaitu adanya konflik kepentingan antara pelaku kegiatan perikanan tangkap dengan pelaku usaha pariwisata bahari "Pantai Tirta Samudra" di Desa Bandengan Kecamatan Jepara Kabupaten Jepara. Nelayan merasa tidak leluasa dalam menambatkan kapalnya di area yang sudah dibangun hotel atau restoran, sebagaimana yang dikemukakan oleh Ketua Himpunan Nelayan Seluruh Indonesia (HNSI) Kabupaten Jepara (Suara Merdeka.com, 24 April 2015). Faktor konversi lahan juga menjadi hal yang sangat krusial dimana banyak lahan kosong berubah fungsi menjadi bangunan baru. Chrisman dan Muktiali (2015) menyebutkan bahwa, dalam kurun waktu 13 tahun (2001-2014) telah dibangun 6 (enam) hotel dan 2 (dua) homestay di area sekitar tempat wisata yang sebelumnya berupa lahan kosong. Kondisi pesisir Bandengan sendiri merupakan wilayah yang rawan terhadap bencana abrasi (Bappeda Jepara, 2014). Hal tersebut jika tidak diatur ruang pemanfaatannya, dikhawatirkan dapat menyebabkan konflik penggunaan yang lebih besar serta menurunkan kualitas lingkungan pesisir bahkan kerusakan lingkungan pesisir. Adanya fakta-fakta tersebut mendorong Pemerintah untuk melakukan upaya pengelolaan wilayah pesisir terpadu melalui perencanaan penataan ruang pesisir berbasis zonasi. Penyusunan rencana zonasi wilayah pesisir merupakan salah satu upaya yang dilakukan Pemerintah dalam rangka mengatasi segala permasalahan wilayah pesisir terkait perbedaan pemanfaatan ruang. Pada kenyataannya, keterlibatan para pemangku kepentingan (stakeholder), khususnya Desa Bandengan sangat minim. Hal tersebut terlihat dari tingkat kehadiran stakeholder dari Desa Bandengan relatif sedikit dalam mengikuti Focus Grup Discussion (FGD) kegiatan penyusunan rencana zonasi wilayah pesisir. Penelitian ini bertujuan untuk mengkaji persepsi dan partisipasi stakeholder dalam penyusunan rencana zonasi wilayah pesisir dengan sasaran penelitian antara lain: 1) Mengidentifikasi tahapan penyusunan rencana zonasi wilayah pesisir; 2) Mengidentifikasi stakeholder pesisir; 3) menganalisa persepsi dan partisipasi stakeholder dalam penyusunan rencana zonasi wilayah pesisir; 


\section{METODE PENELITIAN}

Metode yang digunakan dalam penelitian ini yaitu kualitatif, dimana teknik pengumpulan data primer mengggunakan wawancara mendalam yang didukung dengan observasi, sedangkan pengumpulan data sekunder menggunakan kajian literatur dan telaah dokumen. Teknik sampling menggunakan snowball sampling dengan informan awal berasal dari Dinas Kelautan dan Perikanan Kabupaten Jepara dan Bappeda Kabupaten Jepara. Teknik analisis pada penelitian ini menggunakan analisis interaktif yang terdiri dari reduksi data, sajian data dan penarikan simpulan/verifikasi. Uji kredibilitas data dalam penelitian ini menggunakan teknik triangulasi.

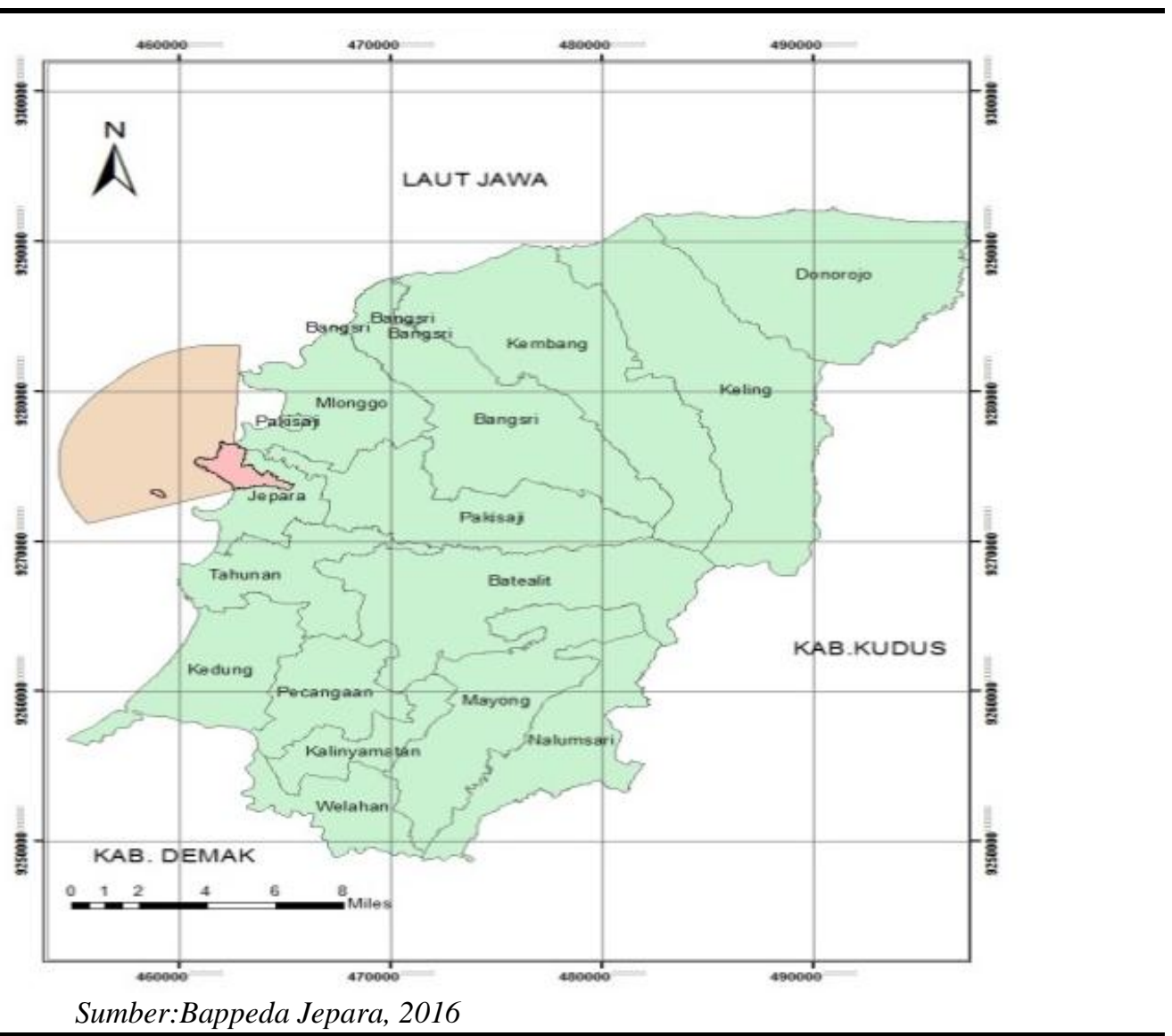

Gambar 1. Deliniasi Lokasi Penelitian

\section{METODE PENYUSUNAN RENCANA ZONASI WILAYAH PESISIR DI KABUPATEN JEPARA}

Kabupaten Jepara merupakan salah satu kota atau kabupaten yang berada di Provinsi Jawa Tengah yang berbatasan langsung dengan Laut Jawa, dimana mempunyai kewajiban untuk melaksanakan kegiatan penyusunan rencana zonasi wilayah pesisir dalam rangka pengaturan ruang pesisir dan laut serta dapat dijadikan pedoman dalam rangka pemanfaatan ruang. Pada tahun 2015, Kabupaten Jepara sudah melaksanakan kegiatan penyusunan rencana zonasi wilayah pesisir melalui anggaran dari Kementerian Kelautan dan Perikanan tetapi dengan dikeluarkan Undang-Undang No. 23 Tahun 2014 tentang Pemerintahan Daerah dimana berimbas terhadap perubahan kewenangan dalam pengelolaan pesisir dan laut. Pada awalnya, pengelolaan wilayah pesisir dan laut merupakan kewenangan dari kabupaten atau kota yaitu dari 0-4 mil ke arah laut dihitung dari garis pantai diukur dari garis pasang tertinggi menjadi tidak mempunyai kewenangan lagi 
sehingga kewenangan pengelolaan wilayah pesisir dan laut beralih kepada Provinsi Jawa Tengah. Kewenangan pengelolaan pesisir dan laut Provinsi Jawa Tengah yang pada awalnya hanya dari 4 mil - 12 mil ke arah laut bertambah menjadi 0 mil - 12 mil ke arah laut. Provinsi Jawa Tengah sendiri sebenarnya sudah pernah menyusun rencana zonasi wilayah pesisir dengan dikeluarkan Perda No.4 Tahun 2014, namun adanya UU No. 23 Tahun 2014 tentang Pemerintahan Daerah, dimana terjadi perubahan kewenangan yang menyebabkan rencana zonasi tersebut dilakukan peninjauan kembali atau review. Pada tahun 2016, kegiatan penyusunan rencana zonasi wilayah pesisir di Kabupaten Jepara dilaksanakan kembali dengan anggaran dari Pemerintah Provinsi Jawa Tengah yang melibatkan stakeholder pesisir.

\section{Identifikasi Tahapan Penyusunan Rencana Zonasi Wilayah Pesisir di Kabupaten Jepara}

Rencana zonasi wilayah pesisir di Kabupaten Jepara disusun melalui beberapa tahapan penyusunan dimana beberapa tahapan diantaranya harus melibatkan partisipasi dari stakeholder atau pemangku kepentingan pesisir. Tahapan kegiatan penyusunan rencana zonasi wilayah pesisir di Kabupaten Jepara pada tahun 2016, saat penelitian dilaksanakan berada pada tahapan penyusunan dokumen antara. Tahapan kegiatan tersebut mengacu kepada pedoman teknis penyusunan rencana zonasi wilayah pesisir dan pulau-pulau kecil yang diterbitkan oleh Kementerian Kelautan dan Perikanan, yang disesuaikan dengan Peraturan Menteri Kelautan dan Perikanan Republik Indonesia Nomor 23/Permen-Kp/2016 tentang Perencanaan Pengelolaan Wilayah Pesisir dan Pulau-Pulau Kecil. Tahapan penyusunan rencana zonasi wilayah pesisir mengalami perubahan dimana sebelumnya mengacu pada Peraturan Menteri Kelautan dan Perikanan Republik Indonesia Nomor 34/Permen-Kp/2014 tentang Perencanaan Pengelolaan Wilayah Pesisir Dan Pulau-Pulau Kecil. Perubahan tersebut terdapat pada tahapan awal dan tahapan akhir, pada peraturan yang baru, tahapan awal yaitu pengumpulan dan pengolahan data sedangkan tahapan akhir yaitu penetapan. Sementara itu, pada peraturan yang lama, tahapan awalnya yaitu pembentukan kelompok kerja sedangkan tahapan akhirnya yaitu permintaan tanggapan/saran baru penetapan. Selain itu, tahapan penyusunan rencana zonasi wilayah pesisir berdasarkan peraturan baru lebih sederhana yaitu hanya tujuh tahapan saja, sedangkan berdasarkan peraturan sebelumnya terdapat delapan tahapan. Tahapan penyusunan rencana zonasi wilayah pesisir Provinsi Jawa Tengah dimana di dalamnya terdapat Kabupaten Jepara yaitu:

\section{Pengumpulan dan Pengolahan Data}

Tahapan penyusunan rencana zonasi wilayah pesisir dimulai pada bulan Januari 2016 dengan dikeluarkannya surat keputusan dari Gubernur Jawa Tengah mengenai peninjauan kembali. Sebelum melaksanakan kegiatan kajian penyusunan rencana zonasi wilayah pesisir, terlebih dahulu dilaksanakan sosialisasi mengenai akan diadakannya kegiatan ini yang dilakukan oleh pihak Provinsi Jawa Tengah dan Pemerintah Kabupaten Jepara. Pada bulan februari 2016 dilakukan proses pengadaan jasa konsultan, sehingga kajian dimulai pada bulan april 2016 yang terdiri atas pengumpulan dan pengolahan data, penyusunan dokumen awal, dokumen antara serta dokumen final. Tahapan kajian ini dilaksanakan oleh pihak konsultan atau pihak ketiga yang mendapat mandat dari Dinas Kelautan dan Perikanan Provinsi Jawa Tengah dengan pendampingan dan pengawalan dari pihak Pemerintah dan pemangku kepentingan atau stakeholder. Tahapan pengolahan dan pengumpulan data yaitu mengumpulkan dan mengolah data yang berupa data primer dan data sekunder yang dimulai pada bulan April 2016 dengan hasil berupa laporan pendahuluan yang telah selesai disusun pada bulan Mei sampai Juni 2016. 


\section{Penyusunan Dokumen Awal}

Tahapan penyusunan dokumen awal merupakan lanjutan dari tahapan laporan pendahuluan yang terdiri dari kajian dokumen awal yang telah dilakukan oleh pihak konsultan dan konsultasi publik. Tahapan ini sudah selesai dilaksanakan pada bulan Agustus 2016 dengan telah dilaksanakannya kegiatan konsultasi publik yang berupa FGD. Dokumen awal berisi mengenai tentang peta-peta tematik hasil survey langsung dan pemetaan data sekunder, potensi dan kondisi eksisting wilayah pesisir serta adanya penjabaran isu stategis yang terjadi di wilayah pesisir dan ruang laut yang mempengaruhi kehidupan masyarakat pesisir.

\section{Penyusunan Dokumen Antara}

Hasil dari kesepakatan dokumen awal yang telah diperbaiki dan disusun kembali dengan memasukkan hal-hal yang menjadi saran dan pertimbangan dari stakeholder merupakan tahapan penyusunan dokumen antara. Tahapan dokumen antara meliputi petapeta rencana alokasi ruang dan draf ranperda. Pada tahapan penyusunan dokumen antara, terdapat tahapan penentuan usulan alokasi ruang yang terdiri dari penentuan usulan kawasan, zona, sub zona, dan/atau pemanfaatannya. Tahapan ini merupakan tahapan analisis yang disesuaikan dengan kondisi eksisting wilayah pesisir sehingga dapat direncanakan alokasi ruang yang cocok untuk diterapkan di wilayah pesisir dan laut. Penentuan alokasi ruang laut tidak hanya didasarkan atas hasil kajian saja, tetapi juga didasarkan masukan dan pertimbangan oleh pemangku kepentingan atau stakeholder. Hal tersebut dilakukan untuk mengetahui apakah penentuan alokasi ruang pesisir dan laut yang telah dikaji oleh pihak konsultan dan pemerintah sesuai dengan kondisi eksisting wilayah pesisir dan laut. Peran stakeholder sangat penting dalam memverifikasi hasil kajian dari dokumen antara ini.

\section{Penyusunan Dokumen Akhir}

Tahapan penyusunan dokumen akhir merupakan hasil perbaikan dokumen antara yang telah disepakati oleh para stakeholder pesisir. Tahapan ini merupakan bahan naskah akademis sebagai bahan penyusunan ranperda dimana naskah akademis ini harus dilakukan penilaian terlebih dahulu oleh Menteri Kelautan dan Perikanan untuk mendapatkan tanggapan atau saran. Setelah hal tersebut didapat, maka akan dilakukan pembahasan rancangan peraturan daerah yang kemudian menjadi Peraturan daerah. Pada tahapan pembahasan ranperda ini sudah masuk pada ranah kewenangan eksekutif dan legislatif.

\section{Identifikasi Stakeholder Pesisir}

Identifikasi pemangku kepentingan dalam penyusunan rencana zonasi wilayah pesisir Kabupaten Jepara didasarkan atas kepentingannya yang terkena dampak dari kegiatan tersebut dimana mengacu pada pendapat yang dikemukakan oleh Crosby (1991) dalam Kismartini dan Yusuf (2015), dimana dibagi menjadi tiga kelompok yaitu stakeholder utama (main stakeholders), stakeholder pendukung (supports stakeholder) dan stakeholder kunci (key stakeholders).

\section{Stakeholder Utama}

Stakeholder utama (main stakeholders) merupakan stakeholder yang menerima dampak positif atau negatif (di luar kemauan) dari kegiatan penyusunan rencana zonasi wilayah pesisir di Kabupaten Jepara serta menggunakan dan memanfaatkan ruang wilayah pesisir dan laut Desa Bandengan sekaligus penerima dampak langsung dan pertama dari adanya kegiatan tersebut. Mengacu hal itu, maka kategori stakeholder utama dalam 
kegiatan penyusunan rencana zonasi wilayah pesisir dan laut di Kabupaten Jepara, studi kasus: Desa Bandengan antara lain : kelompok pembudidaya ikan; kelompok nelayan; kelompok perahu wisata; pengusaha hotel dan restoran; perusahaan pelayaran; kelompok pedagang kaki lima di kawasan wisata bahari "Pantai Tirta Samudra".

\section{Stakeholder Pendukung}

Stakeholder pendukung (supports stakeholders) yaitu stakeholder yang membantu dan menengahi proses pelaksanaan kegiatan penyusunan rencana zonasi wilayah pesisir di Kabupaten Jepara. Stakeholder ini tidak memiliki kaitan kepentingan secara langsung terhadap kegiatan penyusunan rencana zonasi wilayah pesisir di Kabupaten Jepara, tetapi memiliki kepedulian sehingga stakeholder ini dapat berpengaruh terhadap sikap masyarakat dan keputusan pemerintah. Mengacu hal tersebut, yang termasuk stakeholder pendukung pada kegiatan penyusunan rencana zonasi wilayah pesisir di Kabupaten Jepara yaitu: Petinggi dan perangkat Desa Bandengan; Himpunan Nelayan Republik Indonesia (HNSI) Jepara; Forum Nelayan Jepara (Fornel); Dinas Pariwisata Kabupaten Jepara; Dinas PU dan ESDM Kabupaten Jepara; Dinas Perhubungan Laut Kabupaten Jepara; Badan Lingkungan Hidup Jepara; Pengelola Pelabuhan Kabupaten Jepara; Gubernur Jawa Tengah; DPRD Jawa Tengah.

\section{Stakeholder Kunci}

Stakeholder kunci (key stakeholders) yang mempunyai pengaruh kuat atau signifikan terhadap kelangsungan kegiatan penyusunan rencana zonasi wilayah pesisir di Kabupaten Jepara. Stakeholder ini juga memiliki kewenangan dalam hal pengambilan keputusan. Mengacu hal tersebut, maka stakeholder yang termasuk dalam kategori ini yaitu: 1. Dinas Kelautan dan Perikanan Provinsi Jawa Tengah berperan sebagai pemrakarsa, penyelenggara dan team leader dalam kegiatan penyusunan rencana zonasi wilayah pesisir dan pulau-pulau kecil di Provinsi Jawa Tengah, dimana Kabupaten Jepara termasuk didalamnya.

2. Dinas Kelautan dan Perikanan Kabupaten Jepara berperan sebagai Instansi yang mengurusi hal-hal teknis yang berhubungan dengan sektor kelautan dan perikanan, sekaligus instansi yang mempunyai kepentingan dalam pengelolaan wilayah pesisir dan laut di Kabupaten Jepara.

3. Bappeda Jepara berperan sebagai Instansi yang mengurusi mengenai hal-hal yang bersifat perencanaan dan pembangunan di Jepara, salah satunya yaitu penyusunan rencana zonasi wilayah pesisir di Kab. Jepara

\section{PEMBAHASAN}

\section{Identifikasi Peran Stakeholder Pesisir}

Berdasarkan pendapat yang dikemukakan oleh Ondee and Pannarunothai (2008) dalam Kismartini dan Yusuf (2015), peran stakeholder pesisir dipengaruhi oleh tiga atribut kunci yaitu kekuasaan (power), kepentingan (interest) dan pengaruh (influence) sehingga dapat dibagi menjadi 7 (tujuh) kelompok yaitu :

Tabel 1. Pengelompokan Berdasarkan Peran Stakeholder

\begin{tabular}{llll}
\hline No & Kategori Stakeholder & Atribut Kunci & Stakeholder \\
\hline 1 & Definitive stakeholder & kekuasaan (power) & Dinlutkan Prov. Jateng \\
& & $\begin{array}{l}\text { kepentingan (interest) } \\
\text { pengaruh (influences). }\end{array}$ & \\
\hline
\end{tabular}




\begin{tabular}{|c|c|c|c|}
\hline No & Kategori Stakeholder & Atribut Kunci & Stakeholder \\
\hline 2 & Dominant stakeholder & $\begin{array}{l}\text { kekuasaan (power) } \\
\text { pengaruh (influences) }\end{array}$ & $\begin{array}{l}\text { Bappeda Kab.Jepara } \\
\text { Dislutkan Kab. Jepara }\end{array}$ \\
\hline 3 & Dangerous stakeholder & $\begin{array}{l}\text { kekuasaan (power) } \\
\text { kepentingan (interest) }\end{array}$ & $\begin{array}{l}\text { DPRD Jawa Tengah } \\
\text { Gubernur Jawa Tengah }\end{array}$ \\
\hline 4 & Dependent stakeholder & $\begin{array}{l}\text { kepentingan (interest) } \\
\text { pengaruh (influences). }\end{array}$ & $\begin{array}{l}\text { Dinas Pariwisata } \\
\text { Dinas PU dan ESDM } \\
\text { Dinas Perhubungan Laut } \\
\text { Badan Lingkungan Hidup } \\
\text { Pengelola Pelabuhan Jepara }\end{array}$ \\
\hline 5 & Dormant stakeholder & kekuasaan (power) & $\begin{array}{l}\text { Petinggi Desa Bandengan } \\
\text { Sekretaris Desa Bandengan }\end{array}$ \\
\hline 6 & Discretionary stakeholder & pengaruh (influences). & $\begin{array}{l}\text { HNSI Jepara } \\
\text { Fornel Jepara }\end{array}$ \\
\hline 7 & Demanding stakeholder & kepentingan (interest) & $\begin{array}{l}\text { kelompok nelayan "Rahayu Mina" } \\
\text { kelompok pembudidaya ikan "Tirta Mina" } \\
\text { kelompok perahu wisata "wisata bahari" } \\
\text { kelompok pedagang di kawasan "Pantai } \\
\text { Tirta Samudra" Bandengan } \\
\text { pemilik hotel } \\
\text { pemilik restoran/ warung makan } \\
\text { pengusaha pelayaran }\end{array}$ \\
\hline
\end{tabular}

\section{Preferensi Stakeholder Mengenai Pemanfaatan Ruang}

Preferensi stakeholder berguna untuk mengetahui kecenderungan stakeholder dalam memilih. Informasi mengenai preferensi stakeholder dalam penyusunan rencana zonasi wilayah pesisir di Kabupaten Jepara dapat membantu dalam memudahkan kesepakatan antara para stakeholder. Besarnya potensi wilayah pesisir mendorong berbagai pihak untuk menggunakan ruang di wilayah pesisir sehingga berpotensi menimbulkan konflik penggunaan ruang. Kondisi tersebut juga terjadi di Desa Bandengan Kecamatan Jepara Kabupaten Jepara, dimana akibat pesatnya perkembangan di sektor pariwisata bahari "Pantai Tirta Samudra" menyebabkan terjadi konflik antara nelayan dengan pihak pengusaha hotel atau restoran karena nelayan merasa tidak leluasa dalam menambatkan kapalnya di area yang sudah dibangun hotel atau restoran. Padahal area tersebut merupakan area milik publik, tetapi dengan adanya bangunan hotel atau restoran seolah-olah menjadikan area tersebut milik hotel atau restoran. Dengan kata lain, bahwa terjadi privatisasi area di wilayah pesisir yang seharusnya wilayah tersebut merupakan milik publik. Hal tersebut jika terjadi pembiaran dikhawatirkan akan terjadi konflik yang lebih besar di masa depan atau bahkan mampu melemahkan posisi nelayan sehingga dikhawatirkan terjadi penurunan jumlah nelayan di masa depan. Pada awal penelitian diketahui bahwa terdapat konflik antara sektor pariwisata bahari dengan sektor perikanan tangkap dimana nelayan tidak leluasa dalam menambatkan kapalnya di area yang telah dibangun hotel atau penginapan, tetapi dalam perkembangannya ditemukan penemuan baru bahwa konflik yang terjadi tidak hanya itu, tetapi juga terdapat potensi konflik antara pelabuhan (jalur pelayaran) dan area konservasi Pulau Panjang. Adanya kapal-kapal yang melewati jalur pelayaran antara pesisir Bandengan dan perairan di sekitar Pulau Panjang dapat menyebabkan bahkan memperparah tingkat abrasi di area tersebut. Wilayah Pesisir bagian selatan Desa Bandengan merupakan daerah lingkungan kepentingan (DLKP) pelabuhan Jepara yang berlokasi di Desa Ujungbatu. Sementara itu, pesisir Desa Bandengan bagian selatan seluruhnya dan sebagian pesisir barat Desa Bandengan merupakan kawasan konservasi 
terkait dengan keberadaan Pulau Panjang, selain itu sepanjang pesisir Bandengan bagian selatan terdapat tutupan karang dengan prosentase jumlah yang dikategorikan sedang.

Temuan baru yang lain adalah adanya jalur pelayaran di antara pesisir Bandengan dan perairan di sekitar Pulau Panjang yang berpotensi menimbulkan konflik antara kapal pelayaran dengan kapal nelayan. Hal tersebut dikhawatirkan dapat memicu terjadinya kecelakaan laut antara kapal pelayaran dan kapal nelayan. Kapal pelayaran biasanya mempunyai alur yang telah ditetapkan dan dilengkapi dengan peralatan yang canggih, salah satunya yaitu GPS sehingga dapat memudahkan dalam menentukan lokasi pelayaran di laut. Kondisi berbeda, terjadi pada kapal nelayan dimana kapal yang dipakai untuk melakukan penangkapan ikan tidak dilengkapi dengan peralatan yang canggih seperti GPS dan sebagai. Mengingat bahwa sebagian besar kapal nelayan di Desa Bandengan khususnya dan Kabupaten Jepara pada umumnya merupakan kapal penangkap ikan berupa perahu motor tempel dimana hanya dilengkapi dengan mesin motor tanpa peralatan yang canggih dan daya jangkau berlayar yang rendah. Rendahnya pengetahuan dan wawasan nelayan mengenai jalur pelayaran dan penangkapan ikan juga memperparah kondisi tersebut.

Berdasarkan hasil penelitian menunjukkan bahwa stakeholder tersebut mempunyai beberapa kecenderungan dalam memilih jenis penggunaan ruang pesisir dan laut Desa Bandengan. Salah satunya adalah pengunaan ruang untuk pariwisata bahari, dimana banyaknya stakeholder yang lebih memilih pariwisata sebagai jenis pemanfaatan ruang pesisir Desa Bandengan dikarenakan oleh pemikiran bahwa sektor pariwisata mampu meningkatkan kesejahteraan mereka secara signifikan dibandingkan sektor yang lain. Lebih dari separuh sampel stakeholder mengemukakan lebih memilih pemanfaatan ruang pesisir dan laut di Desa Bandengan digunakan sebagai pariwisata bahari. Sementara itu, stakeholder yang mempunyai kecenderungan mengenai jenis pemanfaatan ruang yang cocok diterapkan di Desa Bandengan yaitu perpaduan antara pariwisata dan perikanan beralasan bahwa sektor perikanan merupakan sektor yang mampu mendukung sektor pariwisata di Bandengan sehingga kedua sektor tersebut diharapkan mempunyai proporsi ruang yang sama. Salah satu contohnya adalah adanya suplai ikan-ikan laut ke warung makan atau restoran dan hotel di pesisir Bandengan. Tidak jarang wisatawan yang datang ke pariwisata bahari "Pantai Tirta Samudra" Bandengan tidak hanya ingin menikmati suasana pantainya saja tetapi juga ingin menikmati makanan laut atau yang sering disebut wisata kuliner. Wisata kuliner di Desa Bandengan berupa makanan laut merupakan salah satu tempat yang sering dituju oleh wisatawan, salah satu sebabnya karena lokasinya yang masih berada di daerah kota sehingga mudah untuk dijangkau baik kendaraan bermotor maupun mobil. Kondisi jalan yang relatif baik dengan kondisi geografis yang datar juga memudahkan para wisatawan untuk menjangkau lokasi pariwisata tersebut. Ikan-ikan laut yang disuplai ke warung makan juga relatif masih segar yang dapat menambah kenikmatan rasa masakan dan menjadi ciri khas di Bandengan sehingga menarik wisatawan untuk datang kembali.

Berdasarkan Gambar 2 menunjukkan bahwa preferensi stakeholder cenderung pariwisata bahari yang mempunyai ruang paling besar untuk diterapkan di Bandengan, dimana lebih diarahkan ke bagian barat dan selatan dari pesisir Bandengan. Walaupun ada beberapa pemanfaatan ruang lainnya seperti budidaya laut, penangkapan ikan berkelanjutan dan area konservasi. Area konservasi difokuskan ke daerah di sekitar Pulau Panjang dimana sudah ditetapkan oleh Pemerintah Kabupaten Jepara sebagai Taman Pulau Kecil Pulau Panjang. Sementara panjang tetapi di luar area konservasi, hal tersebut disebabkan wilayah tersebut mempunyai ekosistem pesisir yang lengkap dengan kondisi yang masih baik dan sebaran spesies yang besar sehingga mengindikasikan potensi ikan yang besar di daerah tersebut. Penangkapan pada wilayah tersebut tetap memperhatikan keberlanjutan ekosistem pesisir sehingga sumberdaya ikan tetap lestari walaupun ditangkap. Area budidaya laut diarahkan ke bagian paling selatan pesisir Bandengan karena daerah tersebut merupakan 
daerah tambak-tambak dan yang paling penting tidak mengganggu zona pariwisata bahari sehingga dapat meminimalkan itu, untuk zona penangkapan berkelanjutan diarahkan kepada perairan di sekitar pulau konflik pemanfaatan. Sementara itu, untuk alur pelayaran merupakan alur yang biasanya dipakai oleh kapal-kapal dari daerah Rembang, Surabaya dan sebagainya yang ingin menuju ke arah Semarang (Pelabuhan Tanjung Emas Semarang) dan sebaliknya. Area alur pelayaran dengan area penangkapan ikan merupakan area dengan tingkat rawan konflik yang tinggi

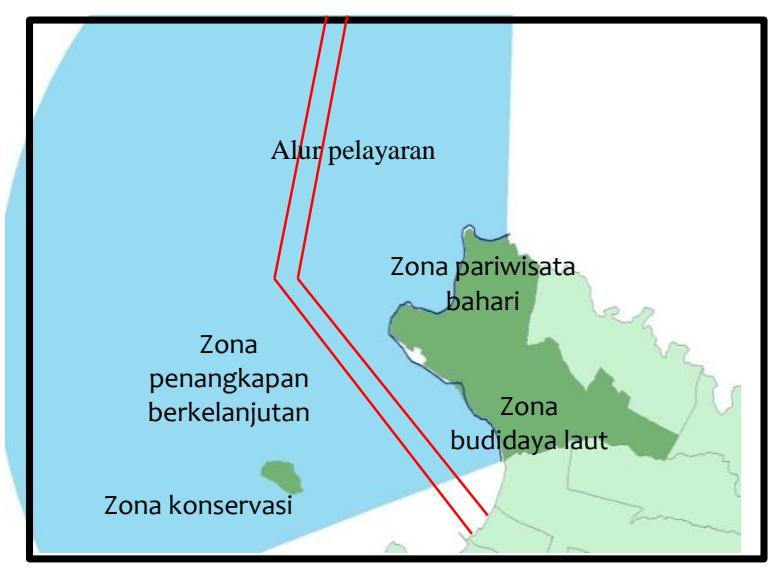

Gambar 2. Peta Rencana Zonasi di Bandengan Berdasarkan Preferensi Stakeholder

\section{Preferensi Stakeholder Mengenai Tipe Pengelolaan yang Disukai}

Pengelolaan merupakan salah satu upaya untuk mengendalikan pemanfaatan ruang di wilayah pesisir, khususnya Desa Bandengan. Dengan adanya pengelolaan yang baik diharapkan mampu mengatur pemanfaatan ruang secara baik pula. Desa Bandengan merupakan salah satu lokasi yang rawan terjadi bencana abrasi, terdapat dua titik lokasi yang merupakan daerah rawan bencana abrasi (Bappeda, 2014). Dengan melihat kondisi tersebut, tipe pengelolaan yang diharapkan tidak hanya dapat meminimalkan konflik antar pemanfaatan tetapi juga dapat menjaga keberlanjutan sumberdaya pesisir. berdasarkan hasil penelitian menunjukkan bahwa Sebagian besar stakeholder lebih memilih pariwisata sebagai tipe pengelolaan yang disukai untuk diterapkan di Desa Bandengan. Hal tersebut dikarenakan bahwa stakeholder tersebut merasa bahwa sektor pariwisata merupakan sektor yang mampu meningkatkan pendapatan dan kesejahteraan mereka serta mampu membuka lapangan pekerjaan baru dibandingkan sektor yang lain. Sementara itu, beberapa stakeholder memilih tipe pengelolaan yang mengarah kepada pengelolaan yang bersifat perpaduan antara pariwisata dan perikanan untuk diterapkan di pesisir Desa Bandengan. $\mathrm{Hal}$ tersebut dikarenakan bahwa stakeholder merasa bahwa sektor perikanan mampu mendukung sektor pariwisata sehingga perlu dikelola dan dikembangkan untuk menjadi salah satu potensi unggulan di Desa Bandengan. Alasan lain yaitu, jika sektor pariwisata di Desa Bandengan terjadi penurunan di masa mendatang, sektor perikanan dapat menjadi sektor unggulan yang dapat menopang kesejahteraan masyarakat sekitar dan tanpa ada kekhawatiran terjadinya penurunan pendapatan dan tingkat kesejahteraan masyarakat sekitar. Hal tersebut didasarkan bahwa Desa Bandengan mempunyai garis pantai yang terpanjang di Kecamatan Jepara sehingga mengindikasikan potensi sumberdaya pesisir dan laut yang relatif besar 


\section{Preferensi Stakeholder Mengenai Intervensi Pengelolaan di Masa Depan}

Pengelolaan yang baik yaitu pengelolaan yang melibatkan berbagai pihak dimana diharapkan bahwa tipe pengelolaan tersebut mampu menampung dan merealisasikan seluruh kepentingan stakeholder. Pada kenyataanya, hal tersebut sulit untuk dipenuhi, karena banyak pihak yang ingin kepentingannya saja yang dikelola. Berdasarkan hasil penelitian menunjukkan beberapa kecenderungan stakeholder dalam memilih. Kecenderungan stakeholder lebih memilih keterlibatan dari tiga pihak yaitu pemerintah, swasta, dan masyarakat sebagai intervensi pengelolaan wilayah pesisir di masa depan yang cocok diterapkan di pesisir dan laut Desa Bandengan, dikarenakan bahwa ketiga pihak tersebut atau dengan kata lain disebut Triangle mempunyai peranan yang sangat penting dalam menentukan keberhasilan kegiatan pengelolaan, khususnya dalam penyusunan rencana zonasi wilayah pesisir. Masyarakat merupakan pihak yang dijadikan sebagai pelaku pembangunan, swasta merupakan pihak yang berkuasa terkait dengan sumber pendanaan atau investasi, sementara pemerintah merupakan pihak yang berperan sebagai fasilitator dan penengah diantara pihak masyarakat dan swasta. Ketiga pihak tersebut mempunyai peran masing-masing yang dapat mendukung keberhasilan suatu kegiatan pengelolaan. Masukan dan informasi dari ketiga pihak tersebut sangat penting dalam keberlanjutan pengelolaan di wilayah pesisir. Sementara itu, stakeholder yang memilih intervensi pengelolaan di masa depan yaitu masyarakat saja didasarkan alasan bahwa ada keyakinan bahwa kesejahteraan masyarakat akan meningkat dan respon masyarakat terhadap permasalahan pesisir dan laut dirasa cepat. Alasan tersebut juga berlaku kepada stakeholder yang memilih intervensi pengelolaan wilayah pesisir dimasa depan yaitu swasta saja yang diharapkan mampu mengembangkan potensi pesisir dan laut ke arah yang lebih baik terutama dari segi pengembangan ekonomi. Berbeda halnya, stakeholder yang memilih intervensi pengelolaan di masa depan yaitu pemerintah saja didasarkan alasan bahwa jika dikelola oleh Pemerintah diyakini suasana akan kondusif karena kondisi menjadi aman, dimana pihak pemerintah dapat bertindak sebagai penengah dan fasilitator konflik. Alasan berbeda dikemukakan oleh stakeholder yang memilih perpaduan peran pemerintah dan masyarakat dalam intervensi pengelolaan di masa depan dimana diyakini bahwa kolaborasi antara pemerintah dan masyarakat dapat menciptakan sistem pengelolaan yang ideal karena adanya pelibatan swasta dalam pengelolaan wilayah pesisir dikhawatirkan cenderung berlaku seenaknya dan tidak memperhatikan keberlanjutan sumberdaya pesisir sehingga berpotensi merusak lingkungan pesisir.

\section{Persepsi Stakeholder Mengenai Kondisi Eksisting Wilayah Pesisir}

Persepsi berhubungan mengenai penilaian stakeholder terhadap kegiatan penyusunan rencana zonasi wilayah pesisir di Kabupaten Jepara. Penilaian stakeholder dapat mempengaruhi peran serta stakeholder terhadap kegiatan tersebut. Mengetahui dan memahami kondisi eksisting wilayah pesisir merupakan suatu langkah awal dalam melakukan pengumpulan data terkait kegiatan penyusunan rencana zonasi wilayah pesisir di Kabupaten Jepara. Hal tersebut juga dapat digunakan untuk mengetahui kondisi fisik, permasalahan dan potensi dari pesisir Desa Bandengan berdasarkan persepsi stakeholder sehingga berperan penting dalam menentukan arah pengelolaan yang akan dilakukan. Berbagai persepsi dikemukakan oleh stakeholder mengenai kondisi eksisting wilayah pesisir Desa Bandengan. Pendapat dari beberapa stakeholder menyebutkan bahwa permasalahan utama di Bandengan yaitu abrasi. Abrasi merupakan salah satu bencana atau bentuk kerusakan lingkungan pesisir yang diakibatkan oleh gelombang laut dan hal tersebut sering terjadi di Kabupaten Jepara. Salah satu riwayat suram mengenai bencana pesisir ini yang terjadi di Kabupaten Jepara yaitu berpindahnya tiga desa di Kecamatan Kedung yaitu Desa Semat, Desa Tanggultare dan Desa Bulak ke arah daratan sejauh 250 meter dari tempat 
semula yang diakibatkan oleh pengikisan pantai. Abrasi pantai juga membuat rusaknya hutan bakau daerah tersebut dimana telah terjadi pengurangan hutan mangrove seluas 37,82 ha berdasarkan penelitian yang dilakukan selama lima tahun dari tahun 1998 sampai tahun 2002 (Anna dkk, 2010). Kondisi eksisting yang lain yaitu adanya pelarangan penambangan pasir laut dan pengambilan karang secara berlebihan yang dahulu pernah dilakukan di Desa Bandengan, tetapi beberapa tahun terakhir ini, sudah tidak dilakukan lagi karena adanya peraturan dan anjuran pelarangan dari pihak pemerintah karena merusak lingkungan. Sementara itu, kegiatan budidaya ikan dan rumput laut juga dilakukan di pesisir Desa Bandengan serta adanya rute pelayaran yang melewati pesisir dan laut Bandengan yang dapat memperparah tingkat abrasi di Bandengan dan Pulau Panjang. Berbeda dengan hal tersebut, beberapa stakeholder malah meyakini bahwa kondisi wilayah pesisir Bandengan masih dikatakan baik. Kondisi saat ini yang sempat menimbulkan perbincangan yaitu adanya reklamasi pantai yang dilakukan oleh D'season hotel di pesisir Bandengan dimana mereklamasi pantai kembali ke kondisi semula, karena daerah tersebut merupakan daerah rawan abrasi.

\section{Persepsi Stakeholder Mengenai Manfaat, Aturan, dan Sanksi Rencana Zonasi Wilayah Pesisir}

Rencana zonasi wilayah pesisir baik manfaat, aturan maupun sanksi juga diperkirakan hampir sama dengan yang ada di dalam rencana tata ruang wilayah. Perbedaannya hanya berada pada wilayah atau ruangnya saja, kalau rencana tata ruang wilayah merupakan pedoman untuk mengatur wilayah darat, sedangkan rencana zonasi wilayah pesisir mengatur wilayah pesisir dan laut. Persepsi stakeholder menunjukkan bahwa rencana zonasi berguna sebagai pengaturan ruang pesisir dan laut sehingga dapat meminimalkan konflik pemanfaatan di laut dan sebagai dasar pengeluaran ijin pengelolaan ruang laut. Rencana zonasi wilayah pesisir disusun atas dasar analisis konflik yang terjadi di ruang laut. Aturan secara pasal per pasal belum dibuat tetapi aturan secara umum sudah ada yaitu peraturan perundang-undangan berlaku terkait dengan pengelolaan wilayah pesisir. Sanksi pun belum dibuat secara jelas, baru proses menyusun, bahkan diperkirakan aturan dan sanksi dalam rencana zonasi wilayah pesisir hampir sama dengan yang ada di dalam rencana tata ruang wilayah (RTRW). Salah satu hal yang menjadi kekawatiran yaitu adanya penegakan aturan dan sanksi yang kurang tegas sehingga harapannya hal tersebut tidak terjadi.

\section{Persepsi Stakeholder Mengenai Keberadaan RZWP Perlu Dipertahankan di Masa Depan}

Berdasarkan hasil penelitian menunjukkan bahwa seluruh informan mempunyai persepsi bahwa rencana zonasi wilayah pesisir perlu dipertahankan keberadaannya. Hal tersebut didasarkan alasan bahwa rencana zonasi wilayah pesisir merupakan amanah Undang-Undang dan sebagai acuan dalam mengeluarkan ijin pengelolaan. Rencana zonasi tersebut juga tidak hanya perlu dipertahankan saja tetapi juga perlu dilakukan review setiap lima tahun sekali seperti halnya rencana tata ruang wilayah. Hal tersebut bertujuan untuk menyesuaikan rencana zonasi dengan kondisi eksisting wilayah pesisir dan laut dengan rencana tata ruang wilayah, kondisi eksisting dan rencana pengelolaan ruang yang menjadi kebijakan Pemerintah Daerah.

\section{Partisipasi Stakeholder Berdasarkan Frekuensi Kehadiran}

Keberhasilan kegiatan penyusunan rencana zonasi wilayah pesisir tidak terlepas dari adanya partisipasi stakeholder atau pemangku kepentingan. Hasil Penelitian menunjukkan bahwa frekuensi kehadiran stakeholder utama dapat dikatakan rendah, sedangkan stakeholder pendukung dan stakeholder kunci mempunyai frekuensi kehadiran yang tinggi. Hal tersebut dapat terlihat dari daftar hadir pada kegiatan konsultasi publik pertama yang 
berbentuk focus grup discussion (FGD). Rendahnya frekuensi kehadiran stakeholder utama dikarenakan kurangnya informasi dan sosialisasi kegiatan penyusunan rencana zonasi wilayah pesisir. Penyebab lain yaitu stakeholder tersebut lebih memilih untuk tetap bekerja pada hari sosialisasi dan konsultasi publik dilaksanakan. Mereka beranggapan bahwa hasil pendapatan bekerja lebih besar dibandingkan harus mengikuti kegiatan seperti itu serta tingkat kesadaran stakeholder utama relatif kurang. Pendapat berbeda dikemukakan oleh pihak Bappeda Jepara sebagai instansi yang memfasilitasi kegiatan konsultasi publik, bahwa semua stakeholder pesisir di Kabupaten Jepara telah diundang untuk mengikuti segala kegiatan terkait dengan penyusunan rencana zonasi wilayah pesisir, tetapi pada perkembanganya, akhirnya dipilih stakeholder pesisir sampai tingkat kecamatan saja. Hal tersebut didasarkan alasan adanya keterbatasan kondisi anggaran yang ada serta stakeholder di tingkat kecamatan dianggap sudah mampu mewakili stakeholder desa-desa pesisir.

\section{Partisipasi Stakeholder Berdasarkan Tingkat Keaktifan}

Keaktifan stakeholder dalam memberi masukan dan pertimbangan merupakan salah satu hal yang dapat menunjang keberhasilan dari kegiatan penyusunan rencana zonasi wilayah pesisir di Kabupaten Jepara, khususnya pada tahapan konsultasi publik. Berdasarkan hasil penelitian menunjukkan bahwa partisipasi stakeholder utama berdasarkan tingkat keaktifan dapat dikategorikan rendah. Rendahnya tingkat keaktifan stakeholder utama juga ditunjukkan oleh sedikitnya informasi yang didapat pada saat sesi wawancara, dimana kebanyakan dari stakeholder utama tidak mengetahui dan memahami mengenai rencana zonasi wilayah pesisir. Sementara itu, kurangnya pengetahuan dan informasi mengenai rencana zonasi wilayah pesisir disebabkan oleh kurangnya sosialisasi yang dilakukan oleh pihak Pemerintah. Pihak Pemerintah atau stakeholder kunci juga tidak melibatkan stakeholder dari desa-desa pesisir untuk ikut dalam kegiatan penyusunan rencana zonasi wilayah pesisir di Kabupaten Jepara. Hal tersebut, didasarkan alasan keterbatasan anggaran dan kekhawatiran akan terjadi konflik yang lebih besar. Berbeda halnya, stakeholder pendukung mempunyai kualitas partisipasi berdasar tingkat keaktifan yang dapat dikategorikan "tinggi". Hal tersebut terlihat dari banyaknya masukan atau ide yang sering dikemukakan oleh stakeholder pendukung pada saat konsultasi publik pertama. Walaupun demikian masukan tersebut tidak mempunyai jaminan penuh untuk dapat diterima dan mampu mempengaruhi dokumen perencanaan pada tahap berikutnya. Pihak Pemerintah atau stakeholder kunci hanya mendengarkan semua masukan atau ide-ide yang dikemukakan oleh stakeholder pendukung tetapi tidak serta merta langsung diterima tetapi ditampung dahulu dan keputusan tetap berada di pihak stakeholder kunci.

\section{Partisipasi Stakeholder Berdasarkan Tingkat Pemahaman}

Tingkat pemahaman stakeholder dapat berpengaruh terhadap kualitas dari dokumen perencanaan ini. Peran pemahaman stakeholder yang berguna bagi proses verifikasi, pemberian masukan, pertimbangan, dan perbaikan terhadap kajian dokumen perencanaan. Hasil penelitian menunjukkan bahwa partisipasi stakeholder utama berdasar tingkat pemahaman dapat dikategorikan rendah, dimana stakeholder tersebut tidak mengetahui dan memahami mengenai arti penting dari rencana zonasi wilayah pesisir. Beberapa stakeholder utama malah kurang memahami mengenai kondisi pesisir di Desa Bandengan yang merupakan tempat tinggal mereka. Rendahnya tingkat pemahaman stakeholder utama disebabkan oleh kurangnya penyebaran informasi mengenai kegiatan penyusunan rencana zonasi wilayah pesisir. Penyebab yang lain yaitu kurangnya kepekaan dan kepedulian dari stakeholder utama dalam memahami kondisi pesisir Desa Bandengan. Berbeda halnya, stakeholder pendukung memahami secara jelas mengenai kondisi pesisir Desa Bandengan khususnya dan secara umum memahami tentang permasalahan dan konflik yang terjadi di 
perairan Jepara. Sementara itu, mengenai arti penting dari rencana zonasi wilayah pesisir, stakeholder tersebut hanya mengetahui bahwa definisi dan manfaat dari rencana zonasi wilayah pesisir saja, sedangkan proses kegiatan penyusunan rencana zonasi wilayah pesisir, stakeholder tersebut tidak terlalu paham sehingga kualitas partisipasi stakeholder pendukung dapat dikategorikan "sedang”. Berbeda halnya dengan stakeholder kunci dimana stakeholder tersebut memahami dengan jelas mengenai tahapan atau proses penyusunan rencana zonasi wilayah pesisir di Kabupaten Jepara, kondisi-kondisi pesisir di perairan Jepara, serta berperan penting dalam setiap pengambilan keputusan. Berdasarkan fakta tersebut dapat dikemukakan bahwa kualitas partisipasi stakeholder kunci berdasar tingkat pemahaman dapat dikategorikan "tinggi".

\section{KESIMPULAN}

Adanya perubahan tahapan penyusunan rencana zonasi wilayah pesisir di Kabupaten Jepara mengacu pada peraturan terbaru yaitu Peraturan Menteri Kelautan Nomor 23/PERMEN-KP/2016 tentang perencanaan pengelolaan wilayah pesisir dan pulaupulau kecil serta pada saat penelitian dilaksanakan berada pada tahapan penyusunan dokumen antara. Pembagian stakeholder pesisir mengacu kepada pendapat yang dikemukakan oleh Crosby (1991) dalam kismartini dan yusuf (2015) dibagi menjadi tiga kelompok yaitu stakeholder utama, stakeholder pendukung dan stakeholder kunci. Stakeholder utama terdiri atas kelompok pembudidaya ikan, kelompok perahu wisata, kelompok nelayan, pengusaha hotel dan restoran, perusahaan pelayaran, kelompok pedagang di kawasan wisata bahari " Pantai Tirta Samudra”. Stakeholder pendukung terdiri atas Petinggi dan Perangkat Desa Bandengan, HNSI Jepara, Forum Nelayan Jepara, Dinas Pariwisata, Dinas Perhubungan Laut, Dinas PU \& ESDM, Badan Lingkungan Hidup, Pengelola Pelabuhan Jepara, Gubernur Jawa Tengah, DPRD Jawa Tengah. Stakeholder kunci terdiri atas Dinas Kelautan dan Perikanan Provinsi Jawa Tengah, Dinas Kelautan dan Perikanan Kabupaten Jepara, Bappeda Jepara. Persepsi dan Partisipasi stakeholder utama berdasarkan frekuensi kehadiran, tingkat keaktifan, dan tingkat pemahaman dapat dikategorikan "rendah", sebaliknya persepsi dan partisipasi stakeholder kunci dikategorikan "tinggi". Sementara itu, persepsi dan partisipasi stakeholder pendukung berdasarkan frekuensi kehadiran dan tingkat keaktifan dikategorikan "tinggi" sedangkan berdasarkan tingkat pemahaman dikategorikan "sedang".

\section{DAFTAR PUSTAKA}

Abelshausen, Bieke et al. 2015. Participatory integrated coastal zone management in Vietnam: Theory versus practice case study: Thua Thien Hue province. Journal of Marine and Island Cultures (2015) 4, 42-53

Anna, dkk. 2010. Perencanaan Tataguna Lahan Wilayah Pesisir Berdasarkan Proses Abrasi Di Pesisir Utara Jepara. Seminar Nasional-PJ dan SIG I Tahun 2010.

Asmawi, M Zaenora et al. 2012. Financing Coastal Land Use Planning: A Case Study of LUAS, Malaysia. ICESD 2012: 5-7 January 2012, Hong Kong. APCBEE Procedia 1 ( 2012 ) 325 - 330.

Bappeda Jepara. 2014. Laporan Ak hir Penyusunan DED Penanggulangan Abrasi Laut di Kabupaten Jepara. Kabupaten Jepara

Ca'rcamo, P et al. 2014. Using stakeholders' perspective of ecosystem services and biodiversity features to plan a marine protected area. Jurnal environmental sciensce \& policy 40 (2014) 116-131.

Chrisman, Daniel dan Muhammad Muktiali. 2015. Dampak Keberadaan Obyek Wisata Pantai Tirta Samudra Kabupaten Jepara Terhadap Aspek Perubahan Pemanfaatan Lahan, Dan Sosial-Ekonomi Masyarakat. Jurnal Teknik PWK Volume 4 Nomor 4 Tahun 2015.

Gangai and Ramachandran. 2010. The role of spatial planning in coastal management-A case study of Tuticorin coast (India). Land Use Policy 27 (2010) 518-534..

Giz. 2013. Sustainable Coastal Resources for the Philippines. Deutsche Gesellschaft für Internationale Zusammenarbeit (GIZ) GmbH. Manila, Philippines. April 2013. 
Himes, A. 2007. Performance indicators in MPA management: Using questionnaires to analyze stakeholder preferences. Ocean \& Coastal Management 50 (2007) 329-351.

Kerr, S.A., 2005. What is small island sustainable development about?. Ocean and Coastal Management 48 (2005) 503-524.

Kindermann, G \& M. Gormally. 2013. Stakeholder perceptions of recreational and management impacts on protected coastal dune systems: A comparison of three European countries. Land Use Policy 31 (2013) $472-485$

Kismartini \& Yusuf. 2015. Stakeholders Analysis: Managing Coastal Policy Implementation In Rembang District. Procedia Environmental Sciences 23 ( 2015 ) 338 - 345.

Kojima, et al. 2013. Integrated coastal management as a tool for local governance of coastal resources: A case study of Munakata coastal zone. Ocean \& Coastal Management 81 (2013) 66-76.

Long-chen, J, et al. 2015. The factors affecting stakeholders' acceptance of offshore wind farms along the western coast of Taiwan: Evidence from stakeholders' perceptions. Ocean \& Coastal Management 109 (2015) 40-50.

Mangi, S \& M, Austen. 2008. Perceptions of stakeholders towards objectives and zoning of marine-protected areas in southern Europe. Journal for Nature Conservation 16 (2008) 271-280.

Montgomery, et al. 2016. A table for five: Stakeholder perceptions of water governance in Alberta. Agricultural Water Management xxx (2016) xxx-xxx.

Ourcast. 2010. Integrated Coastal Zone Management Participation Practices In Europe. Directorate-General Environment of the European Commission. European Union.

Peres, C Mani. 2016. Stakeholders perceptions of local environmental changes as a tool for impact assessment in coastal zones. Ocean \& Coastal Management 119 (2016) 135-145.

Portman, M. 2007. Zoning design for cross-border marine protected areas: The Red Sea Marine Peace Park case study. Ocean \& Coastal Management 50 (2007) 499-522

Ramsey, V et al. 2015. Integrated Coastal Zone Management and its potential application to Antigua and Barbuda. Ocean \& Coastal Management xxx (2015) 1-16.

Suara Merdeka. 2015. Pemkab Diminta Tak Gila Investasi. Publikasi tanggal 24 April 2015. http://berita.suaramerdeka.com/smcetak/pemkab-diminta-tak-gila-investasi/

Thomas et al. 2015. Mental models of sea level change: a mixed methods analysis on the Severn Estuary, UK. Global Environmental Change 33 (2015) 71-82.

Yates, K.L., 2014. View from the wheelhouse: perceptions on marine management from the fishing community and suggestions for improvement. Marine Policy 48 (2014) 39-50. 